Volume 10, No.2, March - April 2021

International Journal of Advanced Trends in Computer Science and Engineering

Available Online at http://www.warse.org/IJATCSE/static/pdf/file/ijatcse021022021.pdf

https://doi.org/10.30534/ijatcse/2021/021022021

\title{
Identification of Online Statistical Translation and Text Issues in Communication Technologies
}

\author{
Irum Naz Sodhar ${ }^{1 *}$, Abdul Hafeez Buller ${ }^{2} \&$ Anam Naz Sodhar ${ }^{3}$ \\ ${ }^{1}$ Lecturer, Shaheed Benazir Bhutto University, Shaheed Benazirabad (SBBUSBA), Sindh, Pakistan, \\ E-mail: irumnaz@ sbbusba.edu.pk \\ ${ }^{2}$ Engineer, Quaid-e-Awam University of Engineering, Science \& Technology, Nawabshah, Sindh, Pakistan, \\ E-mail: ah.buller@quest.edu.pk \\ ${ }^{3}$ Postgraduate Student, Quaid-e-Awam University of Engineering, Science \& Technology, Nawabshah, Sindh, \\ Pakistan, E-mail: anumakber10@gmail.com \\ * Corresponding author: Irum Naz Sodhar
}

\begin{abstract}
Now-a-days Artificial Intelligence growing fast towards new communication technologies and it provide easiness to the users as per there demand. Mobile/cell phone is one of the most reliable examples of latest technologies. It is easy to communicate with peoples of different countries and also in different languages. For the communications different technologies were used to solve this major issue around the globe. Translation is one of them to translate the one language to another language. The research methodology is based on the five phases. In this research study, analysis of the text by process on online translator, bilingual corpus (English and Sindhi) were used. After the translation from English to Sindh and Translation from Sindhi to English many issues were faced at the various communication technologies. When input data of large sentence to the translator it takes more time for the translation, but mostly this issue came in translation of text from English to Sindhi. Moreover, the results are based on translated text of English Languages and total three hundred fifty two words (352) were used.
\end{abstract}

Key words: Artificial Intelligence, Communication Technologies, English text, Mobile phone, Sindhi Text, Translation,

\section{INTRODUCTION}

\subsection{Artificial Intelligence}

Artificial intelligence used in every domain of field. The translators are digital in AI that not only used for translation but different meaning of word and also help for analysis of sentiments from word. Sentiments analysis is the task of Artificial intelligence[1] [2]. Now a day's Artificial intelligence mostly used in portable devices. Machine learning is a structure of artificial intelligence that include programming to perform task by using programming and measure the machines how to think and process data as input by using algorithms, and get best results from machines[3]. AI used in almost all social media applications, online shopping, hotels and other devices [4][5][6].
1.1.1 Types of the AI
i. Reactive Machines
ii. Limited Memory
iii. Theory of mind
iv. Self-awareness

\subsubsection{Applications of the AI \\ i. Natural Language Processing \\ ii. Speech Recognition \\ iii. Machine Learning \\ iv. Deep Learning Platforms \\ v. Text Analytics and NLP}

\subsection{AI in Communication Technologies (Cell Phones)}

Now-a-days AI growing fast towards new communication technologies and it provide easiness to the users as per there demand. Mobile/cell phone is one of the most reliable examples of latest technologies. Cell phone is most commonly used in anywhere and everywhere either ordinary cell phone, smart cell phone and android based phones. These cell phones are mostly used by users. These cell phones different applications and lot of features were introduced and provide easiness to the users for communications [7][8][9]. The most important feature of Artificial intelligence face recognition used in smart phones as security purposes to unlock their smart phones. Face recognition uses in $\mathrm{AI}$ and Machine learning algorithms to accurate identify the faces of smart phone owners to unlock their phones. AI improves and add feature in cell phones [10] [11][12]. 


\subsection{AI in Translation of Text}

Now-a-days, it is easy to communicate with peoples of different countries and in different languages[13]. For the communications different technologies were used to solve this major issue around the globe. Translation is one of them to translate the one language to another language [14]. This translation system is the part of $\mathrm{AI}$ and in $\mathrm{AI}$ translation is divided into two different types of translation; one is machine translation and neural network translation. Simply translation is the way of to connect two persons/peoples by using through translator, when both users used different languages. Translation is very helpful for almost every person who uses social media applications [15]. In social media application people used different language everyone cannot understand that's why immediately need of translator, that time very helpful and provide way of communication with almost every person. Translator reduces the gap of communication. Talk about translation two languages are used in between used translator. Language structure and grammar is different[16][17].

\subsection{Data Set}

In this research study two different languages (Sindhi and English) were used. Sindhi language has fifty two letters to form a variety of words as shown in Figure 1(b)[12][18]. Sindhi is morphological rich because contains huge number of letters [12]. In English language twenty six alphabetical letters to form words as shown in Figure 1(a). Now-a-days it is an easy to translate different languages to English and same way to other languages, but for the translation different communication platforms was used.

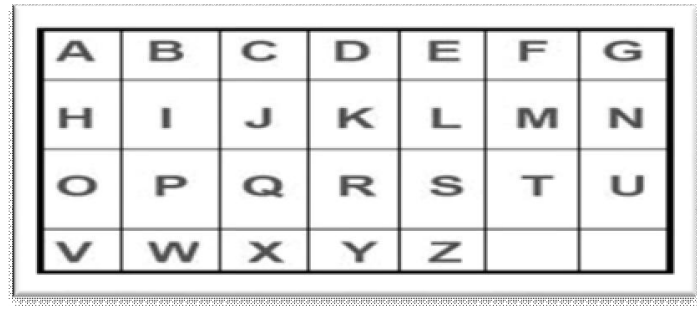

(a) English Alphabet

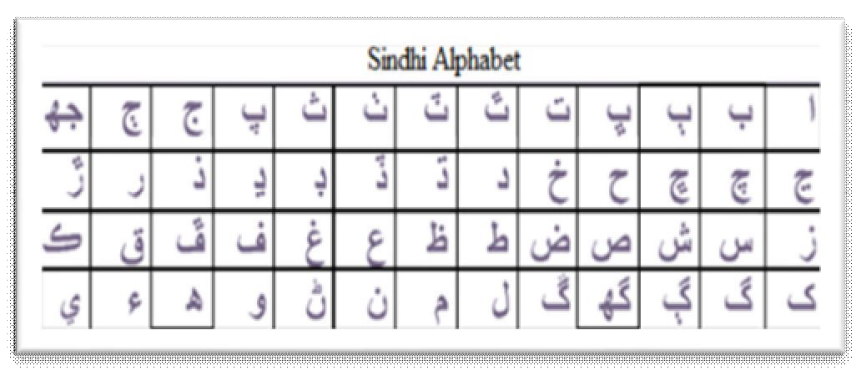

(b) Sindhi Alphabet [10]

Figure 1: English and Sindhi Alphabet

\section{RESEARCH METHODOLOGY}

The research methodology is based on the six phases; first one is the Input data. Input data is collected from different sources. Second phase of this research methodology is arranges the suitable data in proper sequence which is required for the fourth phase of the research. Third part of research is the most important part in which selection of tools/translators/communication technologies were decided[19]. In this phase selected data were translated into required target and in this target issues related to the communication technologies are identified and discussed and this phase of issues is the last phase of the research as shown in Figure 2. This research works is depends on textual analysis of terms, resource of language used as translation to other language. In this research study, analysis of the text by process on online translator, bilingual corpus (English and Sindhi) were used. The corpus of this research based on English and Sindhi, the text related about two famous politicians of two different countries. The main of this research methodology is to translate the text of English language to Sindhi language. During translation many issues were identified and discussed in brief[20][21].

This research methodology depends on three steps such as: first is input text used as English by taking from online Dawn newspaper ${ }^{1}$ retrieved on dated 14 February 2020. Total number of English words used in this research work was two hundred forty one (241). The second step is process text on online translator ${ }^{2}$ by using English input text to translate into Sindhi output text and T shows as text used in methodology. Third step is output in the form of other language after translation.

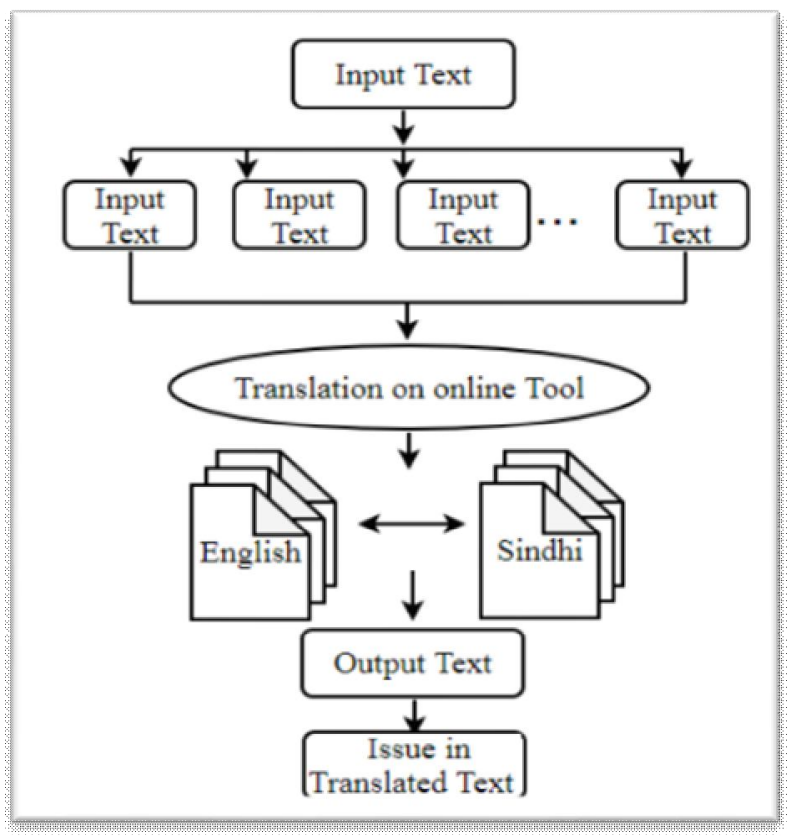

Figure 2: Research Methodology

\footnotetext{
${ }^{1}$ Dawn Newspaper

https://www.dawn.com/news/1532819/turkish-president-to-address-joint-sitti ng-of-parliament-on-feb-14

${ }^{2}$ Translator https://www.stars21.com/translator/english/sindhi/
} 


\section{TRANSLATED TEXT}

Translation is the easy way of communication with one language to another language by using different communication technologies (translators). Many translators are not working properly and still they have lot of issues when translate source language to targeted language. After translation number of count should be variable before and after translation. Grammar and syntax issue, but mostly syntax issues comes when translation task were performed or machine learning task on text. The source text and targeted text shows in Table 1 and Table 2. Source text is English text and the targeted text is Sindh and also from Sindhi to English.

Table 1: English text with Translated into Sindhi text

\begin{tabular}{|c|c|c|}
\hline Text & Original English Text & Translated Sindhi Text \\
\hline $\mathrm{T} 1$ & $\begin{array}{l}\text { Turkish President Recep Tayyip Erdogan will address the joint } \\
\text { sitting of parliament on February 14, announced National } \\
\text { Assembly Speaker Asad Qaiser on Thursday. }\end{array}$ & 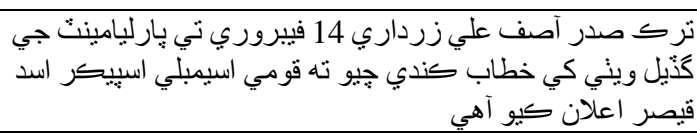 \\
\hline $\mathrm{T} 2$ & $\begin{array}{l}\text { This will be the fourth time that Erdogan addresses the Pakistani } \\
\text { parliament. }\end{array}$ & 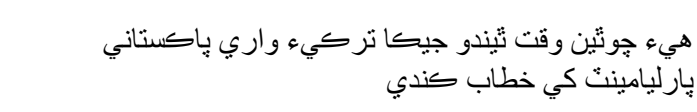 \\
\hline $\mathrm{T} 3$ & $\begin{array}{l}\text { The speaker, during today's NA session, said that he will hold } \\
\text { consultations with all the parliamentary leaders on the } \\
\text { matter, reported Radio Pakistan. }\end{array}$ & 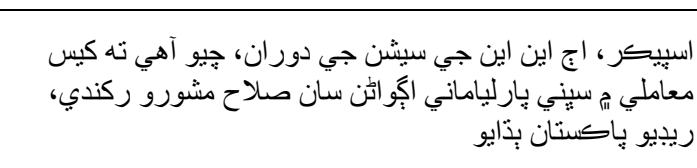 \\
\hline $\mathrm{T} 4$ & $\begin{array}{l}\text { Erdogan is expected to arrive in Pakistan for a two-day visit on } \\
\text { February } 13 .\end{array}$ & 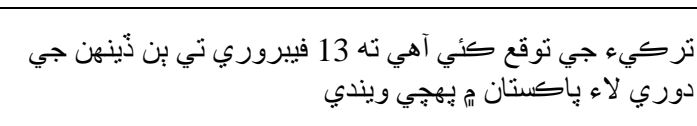 \\
\hline T5 & $\begin{array}{l}\text { The Turkish president was scheduled to pay an official visit to } \\
\text { Pakistan on October } 23 \text { last year to cement relations between the } \\
\text { two countries and to extend full support to Pakistan's stance on the } \\
\text { Kashmir issue. The visit, however, was postponed after Turkey's } \\
\text { involvement with a military offensive against Kurdish militants in } \\
\text { Syria that raised tensions with Washington and other Western } \\
\text { nations. }\end{array}$ & 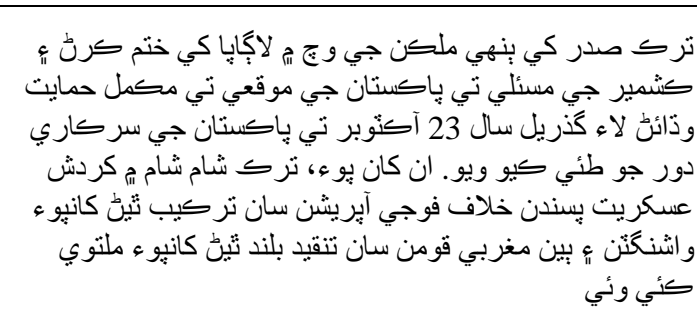 \\
\hline T6 & $\begin{array}{l}\text { Ahead of the October visit, Prime Minister Imran Khan had said: } \\
\text { "The government and the people of Pakistan are looking forward to } \\
\text { accord a warm welcome to President Erdogan." }\end{array}$ & 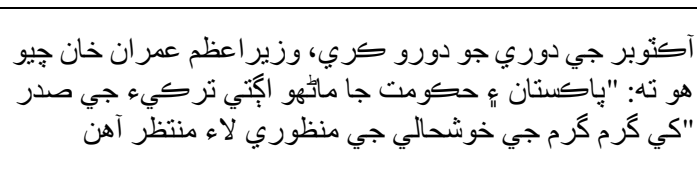 \\
\hline $\mathrm{T} 7$ & $\begin{array}{l}\text { Erodgan last visited Pakistan in 2016, during the PML-N-led } \\
\text { government, during which he also addressed the parliament. He } \\
\text { was accompanied by his wife Emine and a high-level delegation. } \\
\text { They were received at the Nur Khan Airbase by then-Prime } \\
\text { Minister Nawaz Sharif, his cabinet members and senior officials, } \\
\text { first lady Kulsoom Nawaz, his daughter Maryam Nawaz and his } \\
\text { younger brother Shehbaz Sharif. }\end{array}$ & 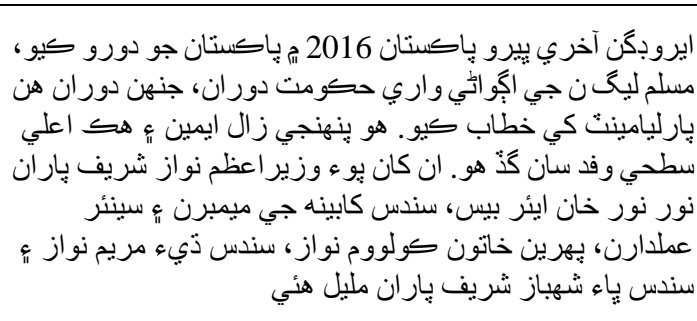 \\
\hline $\mathrm{T} 8$ & $\begin{array}{l}\text { Pakistan Tehreek-i-Insaaf (PTI) lawmakers had boycotted the } \\
\text { session to protest against Nawaz Sharif for his alleged corruption. }\end{array}$ & 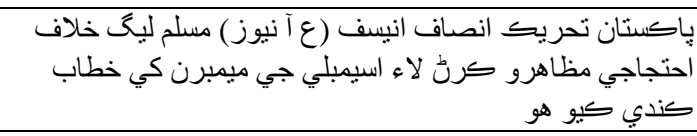 \\
\hline T9 & $\begin{array}{l}\text { eLearning is simple. eLearning is learning utilizing electronic } \\
\text { technologies to access educational curriculum outside of a } \\
\text { traditional classroom. In most cases, it refers to a course, program } \\
\text { or degree delivered completely online. }\end{array}$ & 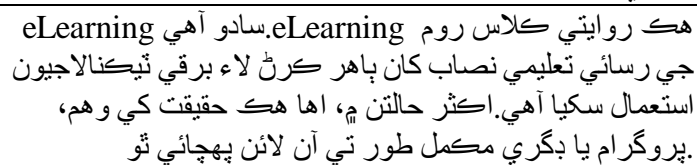 \\
\hline
\end{tabular}

After the translation from English to Sindh and Translation from Sindhi to English many issues were faced at the various communication technologies. These issues were highlighted in below Table 5. When input data of large sentence to the translator it takes more time for the translation, but mostly this issue came in translation of text from English to Sindhi. Same many other issues were addressed in the table. In below table all issues were defined and highlighted with their examples. 
Table 2: Sindhi text with Translated into English Text

\begin{tabular}{|c|c|c|}
\hline Text & Translated Sindhi Text & Translated English Text \\
\hline $\mathrm{T} 2$ & 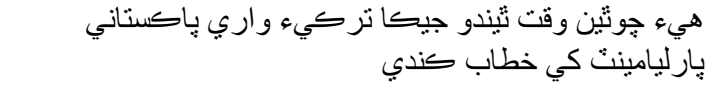 & $\begin{array}{l}\text { This will be the fourth time that Turkey will address the } \\
\text { Pakistani parliament }\end{array}$ \\
\hline $\mathrm{T} 3$ & 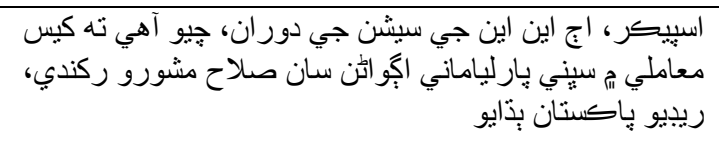 & $\begin{array}{l}\text { Speaker, during today's NNG session, said that he would } \\
\text { consult with all parliamentary leaders in the matter, Radio } \\
\text { Pakistan reported }\end{array}$ \\
\hline $\mathrm{T} 4$ & 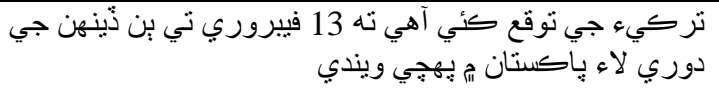 & $\begin{array}{l}\text { Turkey is expected to arrive in Pakistan on February } 13 \text { for a } \\
\text { two-day visit }\end{array}$ \\
\hline T6 & 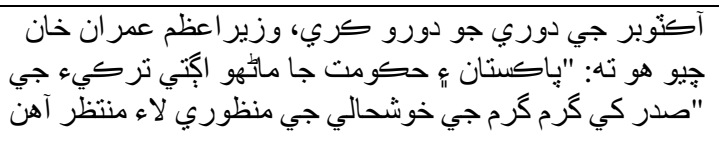 & $\begin{array}{l}\text { During an October visit, Prime Minister Imran Khan said: } \\
\text { "People of Pakistan and the government are looking forward } \\
\text { to Turkey's President's warm welcome. }\end{array}$ \\
\hline $\mathrm{T} 7$ & 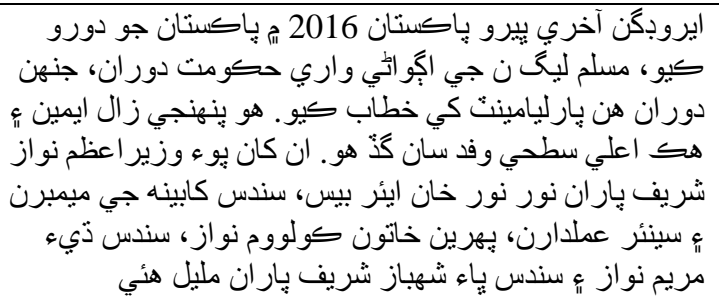 & $\begin{array}{l}\text { Erdogan last visited Pakistan in 2016, during the PML-N } \\
\text { government, during which he addressed the parliament. He } \\
\text { was accompanied by his wife Eminem and a high-level } \\
\text { delegation. Then Prime Minister Nawaz Sharif was received } \\
\text { by Noor Khan Airbase, his cabinet members and senior } \\
\text { officials, first lady Kolom Nawaz, his daughter Maryam } \\
\text { Nawaz and his brother Shahbaz Sharif. }\end{array}$ \\
\hline T9 & 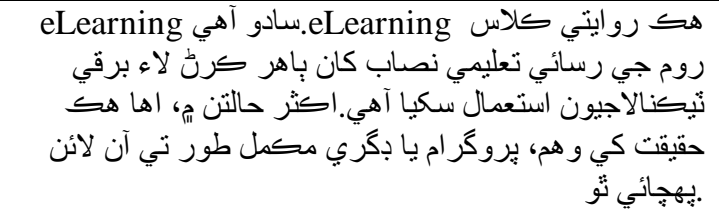 & $\begin{array}{l}\text { eLearning is simple. eLearning a traditional classroom } \\
\text { curriculum out of access to electronic learning technologies } \\
\text { use hy.aksr conditions, a fact that vhm, or degree program } \\
\text { completely online delivered. }\end{array}$ \\
\hline
\end{tabular}

Table 3: Processing English to Sindhi

\begin{tabular}{|c|c|c|c|}
\hline Text & $\begin{array}{c}\text { Total No: } \\
\text { of Words }\end{array}$ & $\begin{array}{c}\text { Total No: of } \\
\text { Characters }\end{array}$ & $\begin{array}{c}\text { Processing Time } \\
\text { (seconds) }\end{array}$ \\
\hline T1 & 23 & 160 & 26.822 \\
\hline T2 & 12 & 77 & 27.614 \\
\hline T3 & 24 & 151 & 21.451 \\
\hline T4 & 15 & 77 & 11.789 \\
\hline T5 & 63 & 398 & 2.767 \\
\hline T6 & 30 & 174 & 2.709 \\
\hline T7 & 65 & 398 & 3.268 \\
\hline T8 & 19 & 127 & 2.748 \\
\hline T9 & 101 & 643 & 39.895 \\
\hline
\end{tabular}

Table 4: Processing Sindhi to English

\begin{tabular}{|c|c|c|c|}
\hline Text & $\begin{array}{c}\text { Total No: } \\
\text { of Words }\end{array}$ & $\begin{array}{c}\text { Total No: of } \\
\text { Characters }\end{array}$ & $\begin{array}{c}\text { Processing Time } \\
\text { (seconds) }\end{array}$ \\
\hline T1 & 25 & 123 & 6.373 \\
\hline T2 & 12 & 68 & 3.648 \\
\hline T3 & 24 & 125 & 2.619 \\
\hline T4 & 18 & 80 & 3.237 \\
\hline T5 & 68 & 315 & 4.198 \\
\hline T6 & 31 & 147 & 4.393 \\
\hline T7 & 72 & 358 & 3.237 \\
\hline T8 & 22 & 111 & 6.265 \\
\hline T9 & 39 & 200 & 3.229 \\
\hline
\end{tabular}


Table 5: Issues in Transliteration

\begin{tabular}{|c|c|}
\hline S.NO & Issues in Transliteration \\
\hline 1 & Input of the large sentence of text in translator, it takes time to translate. \\
\hline 2 & 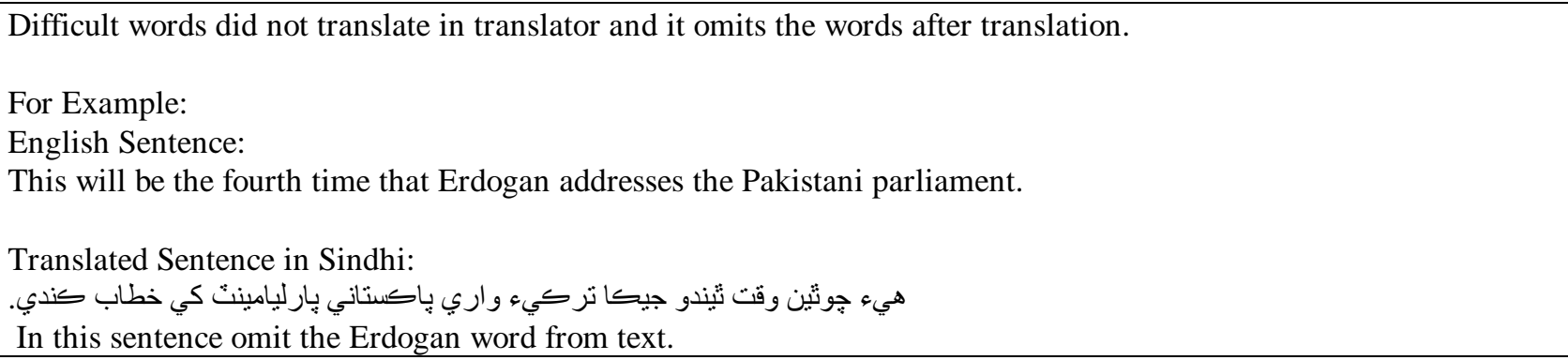 \\
\hline 3 & 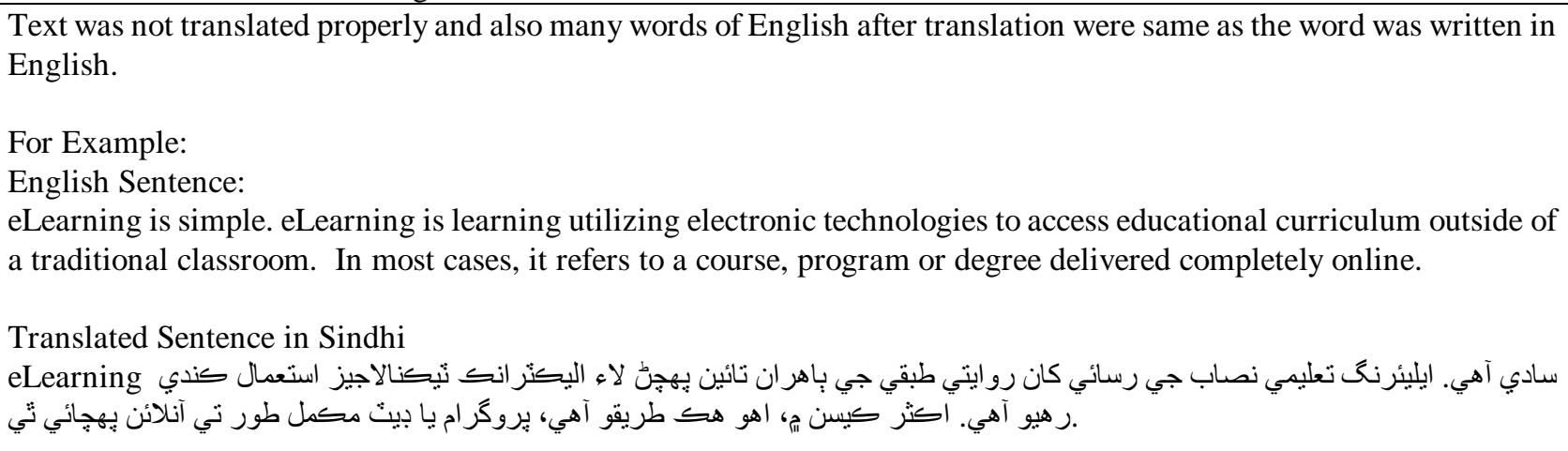 \\
\hline 4 & 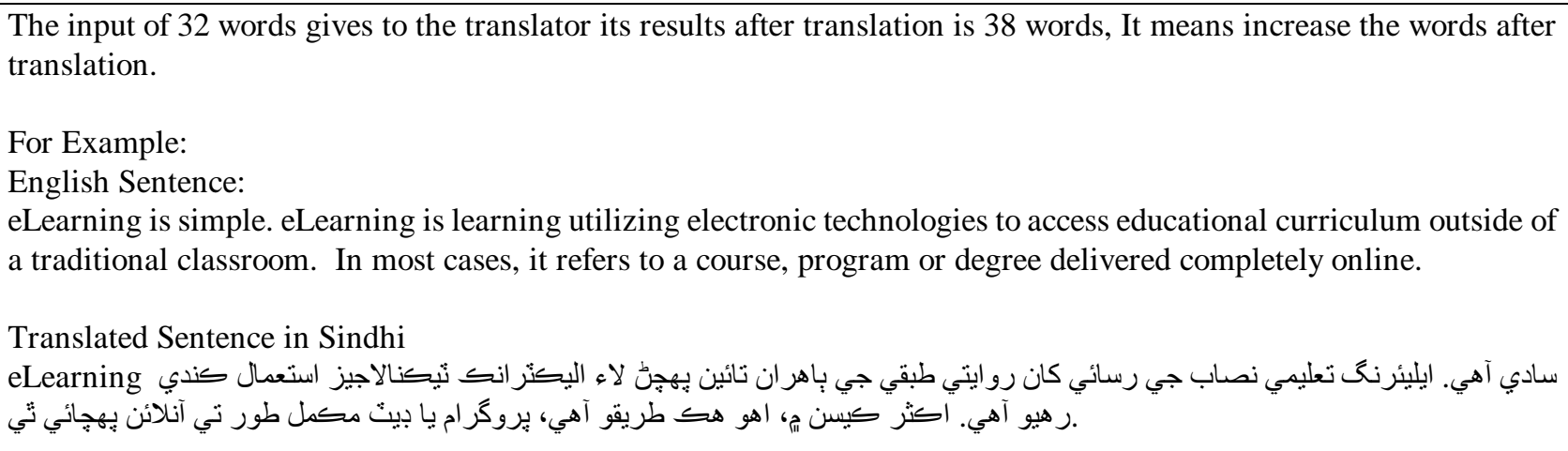 \\
\hline 5 & 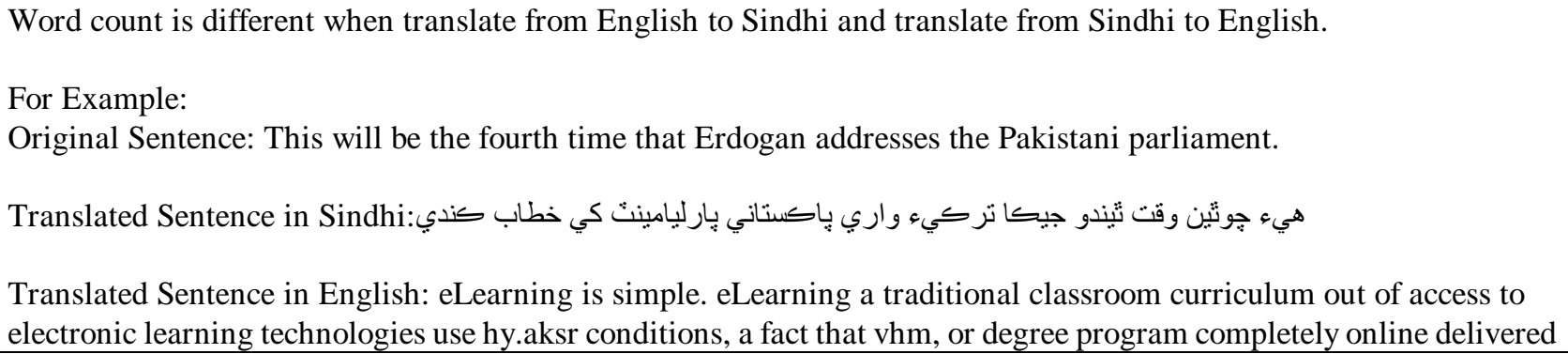 \\
\hline
\end{tabular}




\section{RESULTS AND DISCUSSIONS}

In this research study used nine sentence of original text containing total three hundred fifty two words based on translation as shown in Table 1 and Table 2. Table 1 shows the result of translation perform from original English text to Sindhi text and same way other table 2 is translated from Sindhi text to English text. Number of word counts is different before and after translation of text. The whole statistical results are present in Table 3 and Table 4. In both tables four parameters that is: Text $(\mathrm{T})$, total number of words, total number of characters and processing time were studied. The processing is performed on English to Sindhi and the result of $\mathrm{T} 1$ contains twenty three words, total numbers of characters are one hundred sixty and processing time was 26.822 seconds. T2 contains (twelve words, total number of characters seventy seven and processing time 27.614 seconds). Same procedure was adopted for the T3 contains twenty words, total number of characters seventy one hundred fifty one and processing time was measured 21.451 seconds. T4 contains fifteen words, total number of characters seventy seven and processing time was recorded 11.789 seconds. T5 contains sixty three words, total number of characters three hundred ninety eight and processing time was counted 2.767 seconds. T6 contains thirty words, total number of characters one hundred seventy four and processing time was measured 2.709 seconds. T7 contains sixty five words, total number of characters three hundred ninety eight and processing time was 3.268 seconds. T8 contains nineteen words, total number of characters one hundred twenty seven and processing time was 2.748 seconds. T9 contains one hundred one words, total number of characters six hundred forty three and processing time was obtained 39.895 seconds.

In Table 4 processing time for sentence is performed English to Sindhi the results are T1 contains twenty five words, total numbers of characters are one hundred twenty three and processing time was recorded 6.373 seconds. T2 contains twelve words, total number of characters sixty eight and processing time was 3.648 seconds. T3 contains twenty four words, total number of characters one hundred twenty five and processing time was obtained 2.619 seconds. T4 contains eighteen words, total number of characters eighty and processing time was measured 3.237 seconds. T5 contains sixty eight words, total number of characters three hundred fifteen and processing time was 4.198 seconds. T6 contains thirty one words, total number of characters one hundred forty seven and processing time was 4.393 seconds. T7 contains seventy two words, total number of characters three hundred fifty eight and processing time was 3.237 seconds. T8 contains twenty two words, total number of characters one hundred eleven and processing time was 6.265 seconds. T9 contains thirty nine words, total number of characters two hundred and processing time was 3.229 seconds. These statistical results of translation based on online translator.

A graphical result of total number of words in sentence is shown in Figure 3. This figure is gives us comparison between the sentences translated from English to Sindhi and Sindhi to English. Same way a graphical result of total number of characters in sentence is shown in Figure 4. This figure is gives us comparison between the sentences translated from English to Sindhi and Sindhi to English. Also, graphical result of total processing time for English to Sindhi and Sindhi to English sentences is shown in Figure 5. This figure is gives us comparison between the sentences translated from English to Sindhi and Sindhi to English.

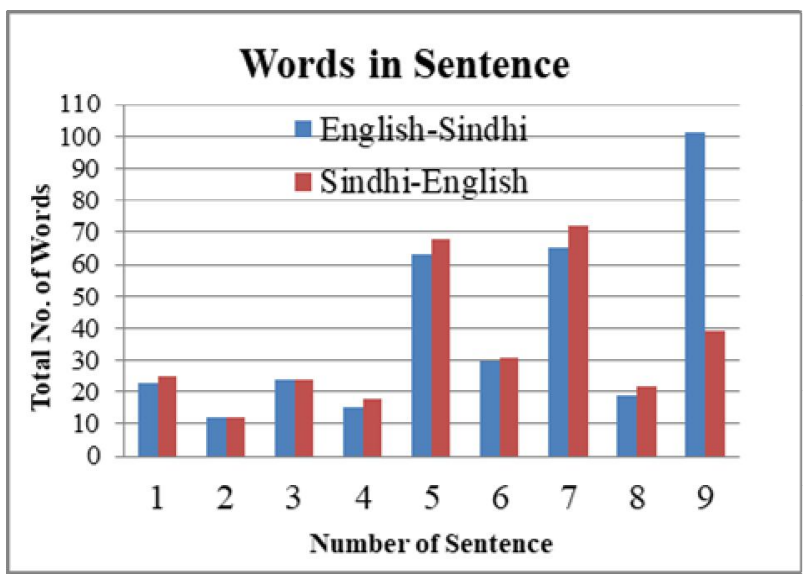

Figure 3: Total Numbers of Words in Sentence

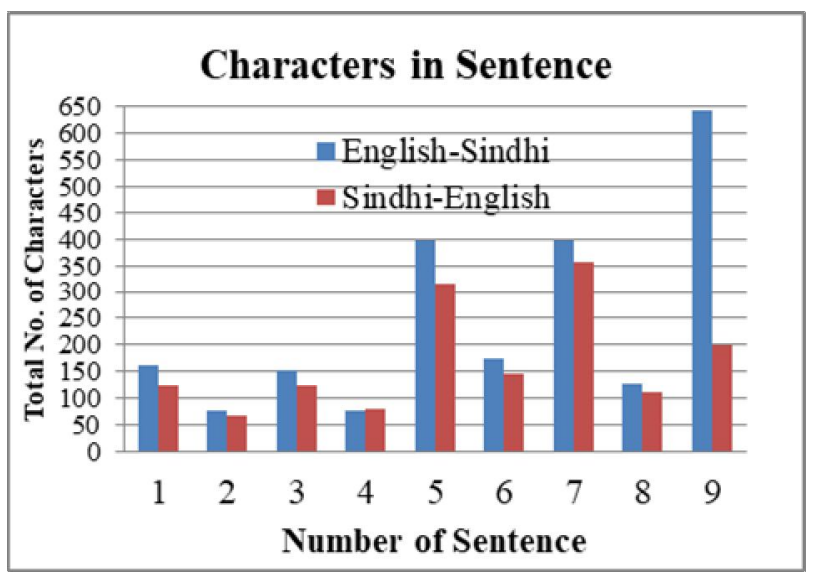

Figure 4: Total Numbers of Characters in Sentence

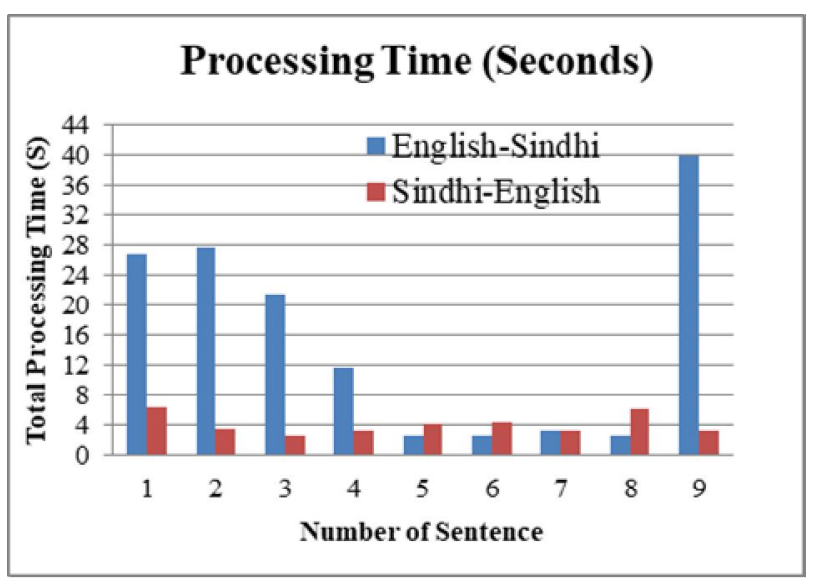

Figure 5: Total Processing Times in Sentence 


\section{CONCLUSION AND FUTURE WORK}

This research is focused on the identification of issues in communication technologies and it based on the online translation of two languages English and Sindhi. English is translated to Sindhi and Sindhi translated to English language. The main aim of the study to highlight the issues in communication and Sindhi Text creates a summary of statistical translated text from original text of English translated to the Sindhi text and translated to English text. When the translators run on different communication platforms (browsers and cell phones) and it may face some issues regarding translation of different languages. Moreover, the results are based on translated text of English Languages and total three hundred fifty two words (352) were used. However, the translated result shows that the translation from English to Sindhi Language takes more time then text translated from Sindhi to English and translation from English to Sindhi Language takes more characters and words then text translated from Sindhi to English. Future work of this research work to translate huge amount of text in different area of fields by using different supervised and unsupervised techniques for the appropriate results and provide easiness to the users at different communication technologies.

\section{REFERENCES}

[1] I. N. Sodhar, A. H. Jalbani, A. H. Buller, M. I. Channa, and D. N. Hakro, "Sentiment analysis of Romanized Sindhi text," in Journal of Intelligent and Fuzzy Systems, 2020, doi: 10.3233/JIFS-179675.

[2] M. V. Valluri, "Artificial Intelligence and Its Applications," Valluri, 2017, doi: 1.

[3] W. Khan, A. Daud, J. A. Nasir, and T. Amjad, "A survey on the state-of-the-art machine learning models in the context of NLP," Kuwait Journal of Science. 2016.

[4] G. Sannino, N. Bouguila, G. De Pietro, and A. Celesti, "Artificial intelligence for mobile health data analysis and processing," Mob. Inf. Syst., vol. 2019, 2019, doi: 10.1155/2019/2673463.

[5] I. N. Sodhar, B. Marina, and A. A. Mirani, "The respondent's haptic on academic universities websites of Pakistan measuring usability," Int. J. Adv. Comput. Sci. Appl., vol. 10, no. 10, pp. 179-184, 2019, doi: 10.14569/ijacsa.2019.0101025.

[6] A. N. Sodhar, Irum Naz, Mirani, Azeem Ayaz and Sodhar, "Automated Usability Evaluation of Government and Private Sector Educational Websites of Pakistan," Inf. Sci. Lett., vol. 8, no. 2, pp. 51-55, 2019, doi: $10.18576 /$ isl/080202.

[7] S. Caro-Alvaro, E. Garcia-Lopez, A. Garcia-Cabot, L. De-Marcos, and J. M. Gutierrez-Martinez, "A Systematic Evaluation of Mobile Applications for Instant Messaging on iOS Devices," Mob. Inf. Syst., vol. 2017, 2017, doi: 10.1155/2017/1294193.

[8] S. Caro-Alvaro, E. Garcia-Lopez, A. Garcia-Cabot, L. De-Marcos, and J. J. Martinez-Herraiz, "Identifying usability issues in instant messaging apps on iOS and android platforms," Mob. Inf. Syst., vol. 2018, no. Im, 2018, doi: 10.1155/2018/2056290.

[9] J. A. P. and T. I. Nelson A. Baloian, Wolfram Luther, "Mobile Collaborative Technologies and Data Science for Smart Systems Nelson," Mob. Inf. Syst., 2019, doi: 10.1109/MITP.2015.115.

[10] I. N. Sodhar, G. M. Solangi, Q. Soomro, A. N. Sodhar, A. Mirani, and A. J. Brohi, "Information Communication and Technology Tools Integration in Higher Education," Int. J. Progress. Sci. Technol., vol. 15, no. 1, pp. 127-133, 2019.

[11] C. Fichten, D. Olenik-Shemesh, J. Asuncion, M. Jorgensen, and C. Colwell, "Higher Education, Information and Communication Technologies and Students with Disabilities: An Overview of the Current Situation," Improv. Access. Digit. Pract. High. Educ., vol. 1, pp. 21-44, 2019, doi: 10.1007/978-3-030-37125-8_2.

[12] I. N. Sodhar, A. H. Jalbani, M. I. Channa, and D. N. Hakro, "Identification of issues and challenges in romanized Sindhi text," Int. J. Adv. Comput. Sci. Appl., vol. 10, no. 9, pp. 229-233, 2019, doi: 10.14569/ijacsa.2019.0100929.

[13] H. Ren, X. Mao, W. Ma, J. Wang, and L. Wang, "An English-Chinese Machine Translation and Evaluation Method for Geographical Names," Int. J. Geo-Information, vol. 9, no. 139, pp. 1-18, 2020, doi: 10.3390/ijgi9030139.

[14] A. Allauzen and H. Bonneau-Maynard, "Training and evaluation of POS taggers on the French MULTITAG corpus," Proc. 6th Int. Conf. Lang. Resour. Eval. Lr. 2008, pp. 3373-3377, 2008.

[15] I. N. Sodhar, A. H. Jalbani, A. H. Buller, E. Study, and S. Language, "AN EMPIRICAL AND STATISTICAL STUDY ON POS TAGGING OF SINDHI SOCIAL MEDIA TEXT," FOURRAFES, vol. 241, no. 1, pp. 72-81, 2020.

[16] A. Lopez, "Statistical machine translation," $A C M$ Comput. Surv., vol. 40, no. 3, pp. 1-49, 2008, doi: 10.1145/1380584.1380586.

[17] P. Koehn, "Adquisición de una segunda lengua en estancias cortas en el extranjero: un análisis actitudinal," Didact. (Lengua y Lit., vol. 20, no. 20, pp. 117-134, 2008, doi: 10.5209/DIDA.19853.

[18] I. N. Sodhar, H. Bhanbhro, Z. H. Amur, A. H. Jalbani, and A. H. Buller, "Sindhi Language Processing on Online SindhiNLP Tool," vol. 4, no. 3, pp. 4-7, 2020.

[19] I. N. Sodhar, A. H. Jalbani, A. H. Buller, and A. N. Sodhar, "Tools Used In Online Teaching and Learning through Lock - Down," no. 8, pp. 36-40, 2020.

[20] I. N. Sodhar, A. H. Jalbani, M. I. Channa, and D. N. Hakro, "Parts of Speech Tagging of Romanized Sindhi Text by applying Rule Based Model," vol. 19, no. 11, pp. 91-96, 2019.

[21] I. N. Sodhar, D. Noor, I. Memon, M. Malik, and C. Author, "A SURVEY OF FACED ISSUES AND CHALLENGES OF UNDERGRADUATE," vol. 11, no. $11, \quad$ pp. 649-654, 2020, doi: 10.34218/IJARET.11.11.2020.061. 